
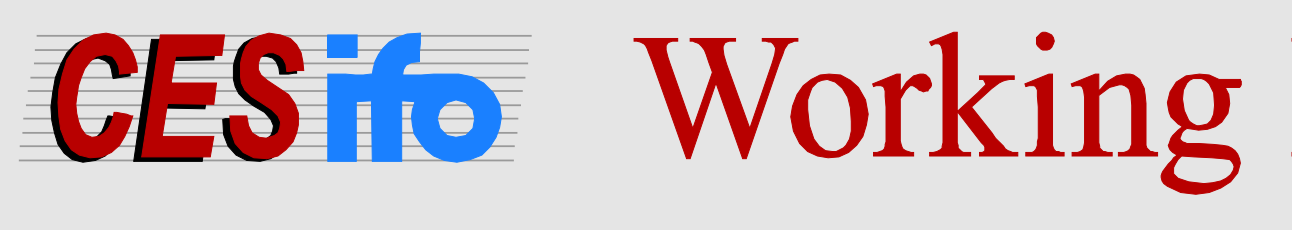

Papers

www.cesifo.org/wp

\title{
Cross-Border Effects of Fiscal Consolidations: Estimates Based on Narrative Records
}

\author{
Shafik Hebous \\ Tom Zimmermann
}

CESIFO WORKING PAPER NO. 4311

CATEgory 6: FisCAl POLICY, MACROECONOMICS AND GROWTH

JUNE 2013

Presented at CESifo Area Conference on Macro, Money \& International Finance, February 2013

An electronic version of the paper may be downloaded

- from the SSRN website:

- from the RePEc website:

- from the CESifo website:

WWW.SSRN.com

www.RePEc.org

www.CESifo-group.org/wp

\section{CESifo}




\title{
Cross-Border Effects of Fiscal Consolidations: Estimates Based on Narrative Records
}

\begin{abstract}
We estimate cross-border spillover effects of fiscal consolidation episodes on output, bilateral trade flows, interest rate, and the exchange rate, employing the new IMF action-based fiscal consolidation data. Results indicate a negative effect of foreign fiscal consolidation policies on domestic output. Regarding the transmission mechanism, our results suggest that fiscal consolidations in foreign economies work their way into the domestic economy by negatively affecting exports. We do not find evidence for an interest rate channel. Trade effects are particularly pronounced for some European countries and are insignificant for others, such as the US and Canada. This is not due to the common currency or to differential specialization in trade.
\end{abstract}

JEL-Code: E620, F410, F420, F150, H500, H600.

Keywords: fiscal consolidation, cross-border fiscal policy effects, fiscal adjustment, fiscal spillover.

Shafik Hebous

Goethe University Frankfurt

Faculty of Economics and Business

Administration / Grüneburgplatz 1

Germany - 60323 Frankfurt am Main

hebous@wiwi.uni-frankfurt.de
Tom Zimmermann

Harvard University

Department of Economics

Littauer Center, Room 200

USA - Cambridge, MA 02138

tzimmerm@fas.harvard.edu

June 2013

We have received useful suggestions from the participants in the 68th annual congress of the IIPF in Dresden, the CESifo Area Conference on Macro, Money and International Finance in Munich, and the Eastern Economic Association Annual Conference in 2013 in New York. The usual disclaimer applies. 


\section{Introduction}

The existence of cross-border effects of domestic fiscal actions is a widespread notion among politicians, many academics, and international institutions such as the International Monetary Fund. In an interview with the Financial Times on 15 March 2010, the current head of the International Monetary Fund (IMF) and the French Finance Minister at that time, Christine Lagarde, stated: "Berlin should consider boosting domestic demand to help deficit countries regain competitiveness and sort out their public finances."

Whereas in the aftermath of the global economic crisis in 2008 the motto was "fiscal stimulus", currently the major concern in the international policy arena is about "fiscal consolidation". The World Economic Outlook (2010; chapter 3) estimates a significant negative short-run effect of a fiscal consolidation on domestic output in a panel of advanced economies. These results stand in contrast to earlier evidence reported in Alesina and Ardagna (1996) and Giavazzi and Pagano (1990) suggesting that fiscal contractions can have expansionary effects. In any case, a significant domestic effect can be transmitted to other countries via international economic linkages, especially through international trade in goods and services. For example, lower income as a result of a fiscal consolidation has, ceteris paribus, negative effects on imports, which in turn has negative effects on incomes of a country's main trading partners. Also, a policy of fiscal consolidation can affect the exchange rate and might lower the domestic interest rate, attracting foreign capital, with contractionary repercussion for foreign economies. Yet, is the fiscal spillover effect quantitatively important?

This paper estimates cross-border effects of fiscal consolidations using a panel of 17 advanced countries in the period from 1978 to 2009. In particular, we do four types of exercises. First, we analyze the effect of foreign fiscal consolidations on domestic output. Second, we use aggregate data to examine three major potential channels of cross-border effects: (1) international trade in goods and services, (2) the interest rate channel, and (3) the exchange rate channel. Third, we use bilateral trade data to estimate the country-specific response to foreign fiscal consolidation shocks. Fourth, we employ trade statistics by commodities in a

bilateral framework to examine whether or not trade in manufactured goods and machines react differently from trade in other categories such as foods and minerals. Furthermore, we explicitly distinguish between fiscal spillover effects before and after the formation of the 
European Monetary Union, and spillover effects of fiscal consolidations during episodes of banking crises and those in periods of no crises.

Our identification strategy relies on the new fiscal-action-based data set provided by Devries et al. (2011). This data set identifies discretionary changes in government spending and taxes that aim to decrease the budget deficit and are not meant to offset high domestic demand. This remarkable feature of the data is accomplished by scrutinising official policy documents for 17 countries in the period from 1978 to 2009 to isolate the policy action from business cycle reactions. The idea of checking historical records to identify exogenous components of fiscal series has been pioneered and applied for the U.S. economy by Romer and Romer (2010). To identify dates of a crisis, we rely on banking crisis data of Reinhart and Rogoff (2010).

We summarise our results as follows. From the standpoint of a domestic economy, foreign fiscal consolidations negatively affect its output. Analysing the transmission mechanisms suggests that this effect is driven by a trade channel while interest rates and exchange rates do not react much. Whenever the reaction of exports to foreign consolidations is significant, it is negative. We find this pattern to be more pronounced for European countries such as France, Germany, Sweden, and the UK. The US seems to be insulated from fiscal shocks from the rest for the world. Regardless of the exported commodity or the incidence of a banking crisis, U.S. exports do not show a significant reaction to fiscal policies in the rest of the world. Results of a before-after analysis indicate that the heterogeneous responses of exports to foreign fiscal shocks are not driven by the formation of the European Monetary Union. ${ }^{1}$

Our paper is one of the first to examine cross-border transmission mechanisms of fiscal consolidation linking bilateral variables to fiscal narrative measures, but is also related to a few recent studies on cross-border effects of a fiscal expansion. Empirically, Feyrer and Jay (2012) use Romer and Romer's (2010) measure to estimate the effects of changes in U.S. tax policy on the rest of the world's current account. Their results suggest that an increase in U.S. taxes leads to worsening foreign current accounts. Carlino and Inman (forthcoming) examine fiscal spillover among US states and provide evidence for a positive job spillover of local states'

\footnotetext{
${ }^{1}$ We note that, even before the EMU, European countries had agreed on semi-pegging their exchange rates in the European Exchange Rate Mechanism (ERM).
} 
deficits to neighboring regions. Auerbach and Gorodnichenko (2013) study fiscal spillovers in a sample of OECD countries, distinguishing effects in recessions and expansions. Earlier studies do not identify exogenous shocks according to narrative records. The identification of fiscal structural shocks in vector autoregression models is heavily debated (see for example, Hebous, 2011). One recent related paper on fiscal spillover effects, by Hebous and Zimmermann (2013), employs a multicountry VAR model (a so-called GVAR model) for the euro area. In this setup, the strategy is to rely on generalised IRFs that include not only the discretionary fiscal component but the total fiscal effects. Their results suggest that if every member country contributes to an expansionary fiscal shock (measured by its relative size in the euro area), then the effect on output is higher than that of a similar-size shock in one country.

This paper proceeds as follows. Section 2 provides theoretical insights into the potential channels of cross-border effects of fiscal consolidations. Section 3 summarises our data and describes our empirical approach. In section 4, we present our main results obtained from aggregate and bilateral panel specifications including data on trade by commodity. Furthermore, we extend the analysis by investigating whether there was a trend break around the introduction of the Euro, and we examine potential differences between spillover effects in periods of crises and periods of no crises. Section 5 concludes.

\section{Theory}

There are two major transmission mechanisms for international effects of domestic fiscal consolidation policies. The first mechanism works through international trade in goods and services, and the second through changes in interest rate differentials. Both mechanisms may entail cross-border links via exchange rate movements.

\subsection{Cross-Border Effects of Fiscal Consolidations through Bilateral Trade Flows}

We reserve the subscript $i$ for the domestic (home) country and the subscript $j$ for a foreign country. Primarily, domestic exports $\left(X_{i}\right)$ depend, inter alia, on foreign income $\left(Y_{j}\right)$ and bilateral exchange rates $\left(P_{j i}\right)$, whereas home imports $\left(M_{i}\right)$ depend on domestic income, 
bilateral exchange rates, and other country-pair factors $Z_{i j}$ such as the distance between the two countries. We can express exports of the home country $(i)$ as the sum of all its trading partners' imports from $i$ :

$$
X_{i}=\sum_{j=0}^{n} M_{j}\left(Y_{j}, P_{j i}, F C_{j}, Z_{i j}\right)
$$

The first international trade spillover channel works through the income effect of a fiscal consolidation. If a foreign fiscal consolidation in the $j$ th country $\left(F C_{j}\right)$ negatively affects the output of country $j$, then $M_{j}$ is expected to decline in total, albeit to various degrees at the bilateral levels. The decrease in country $j$ 's imports from the home country $i$ would feed back into a decline in home exports $X_{i}$ and ultimately home output $Y_{i}$.

The second international trade spillover channel works through the price effect of fiscal consolidation. Fiscal actions can affect the real exchange rate. In this regard, the theory does not provide an unambiguous prediction. For example, according to the classical MundellFleming model, a fiscal contraction decreases the interest rate and therefore also the demand for domestic currency. As a result, under sticky prices, the nominal and the real exchange rates depreciate. From the standpoint of country $j$, a depreciation of $P_{j i}$ boosts exports and at the same time makes imports more expensive. The net effect on the trade balance of country $j$ might be positive or negative. ${ }^{2}$ However, Obstfeld and Rogoff (1995) present an intertemporal model wherein a decrease in government spending can have a positive wealth effect, raising the interest rate and the demand for domestic currency. Under this scenario, the real exchange rate appreciates, which discourages exports. The empirical evidence on this issue is also mixed. Monacelli and Perotti (2010) provide support for the belief that an increase in government spending leads to a depreciation of the real exchange rate and an increase in private consumption. Whereas the results of Monacelli and Perotti (2010) suggest that a budget deficit is associated with a deteriorating trade balance, Kim and Roubini (2008) find that a worsening budget balance improves the trade account.

\footnotetext{
${ }^{2}$ Typically, economists assume that the Marshall-Lerner elasticities' conditions are satisfied, ensuring a positive net effect of a depreciation on the trade balance. Also, note that under the assumption of a small open economy (perfect capital mobility and a predetermined fixed interest rate at the world level) the net effect of fiscal consolidation on output is zero. This is because the improvement in the trade balance offsets the contractionary effect of fiscal consolidation on output.
} 
To sum up, from the perspective of the home country, the income effect of foreign fiscal consolidation decreases home exports, whereas the price (exchange rate) effect on home exports is theoretically ambiguous.

\subsection{Cross-Border Effects of Fiscal Consolidations through Interest Rate Differentials}

Cross-border effects of fiscal consolidations can be transmitted through changes in interest rate differentials. Let $r_{i}-r_{j}$ denote the real interest rate differential between countries $i$ and $j$. We write

$$
r_{i}-r_{j}=f\left(P_{i j}, F C_{i}, F C_{j}\right)
$$

In the Mundell-Fleming world under a flexible exchange rate, a fiscal contraction in country $j$ lowers its real interest rate $\left(r_{j}\right)$ (if it is large enough), increasing, ceteris paribus, the real interest rate differential vis-à-vis country $i$. The relative increase in the $i$ th country's interest rate decreases its private investment. This leads to a negative spillover effect on the $i$ th country due to the foreign fiscal consolidation. Eventually, however, the differential $r_{i}-r_{j}$ will be restored to its initial equilibrium in the case of a small open economy. Another way of viewing cross-border effects through the interest rate is to consider the uncovered interest parity. This no-arbitrage condition states that interest rate differentials are matched by bilateral exchange rate adjustments. Starting from an equilibrium, an increase in the interest rate of country $i$ relative to country $j$ leads to an expected depreciation of country $i$ 's currency relative to currency $j$ in order to equalise returns.

In the case of a fixed exchange rate (e.g., a currency union), a fiscal consolidation has theoretically no effect on the interest rate, since the interest rate is set at the union level. However, a fiscal consolidation in country $j$ can reduce the union interest rate if the country is large enough. This causes spillover effects on the other members of the union.

Recent macroeconomic models rely on a micro-founded dynamic stochastic general equilibrium (DSGE) framework. In these models, the response of the domestic interstate rate to a fiscal policy shock and possible resulting international spillover effects are model dependent. 
Different households' preferences, expectation formations, calibrations of the model, the share of non-forward-looking consumers in the economy, and other model details lead to different interest rate dynamics. Two recent studies explicitly address fiscal spillover effects of fiscal policy in an open DSGE setup. Corsetti, Meier, and Mueller (2010) present a two-country DSGE model according to which financing a fiscal expansion with a mixture of raising taxes and lowering government expenditures in the medium run generates positive cross-border effects. However, Cwik and Wieland (2011) do not find support for positive cross-border effects of fiscal expansions in a model calibrated to the euro area.

Figure 1 summarises international spillover transmission channels of a fiscal consolidation. Overall, the theory predicts that a foreign fiscal consolidation can affect home output through international trade and interest rate effects. Exchange rate effects would be already nested within these two channels. Cross-border fiscal externalities can be dampened, depending on factors such as the size of the country, exchange rate regime, and intertemporal effects.

\section{Data and Empirical Specifications}

\subsection{Data}

Our identification strategy relies on the new fiscal-action-based data set provided by Devries et al. (2011). This data set identifies discretionary changes in government spending and taxes that aim to decrease the budget deficit and are not meant to offset a high domestic demand. Hence, these shocks are meant to be uncorrelated with short-run fluctuations in the domestic economy. This is accomplished by scrutinising official policy documents to isolate the policy action from business cycle reactions. The idea of checking historical records to identify exogenous components of fiscal series has been pioneered and applied for the U.S. economy by Romer and Romer (2010). Devries et al. (2011) extend this idea to a panel of 17 countries for the period from 1978 to 2009. While Romer and Romer provide data at a quarterly frequency, the extended data set contains observations on an annual basis. Figure 2 displays these data. Overall, the data identify 173 episodes of fiscal consolidations during the sample period. Fiscal consolidations are measured in percent of GDP, with a mean consolidation of 0.99 percent and a median consolidation of 0.74 percent. The included 
countries are: Australia, Austria, Belgium, Canada, Denmark, Finland, France, Germany, Ireland, Italy, Japan, Netherlands, Portugal, Spain, Sweden, the UK, and the U.S. Devries et al. (2011) describe the data in detail and document country-specific references. ${ }^{3}$

We collect data on bilateral trade flows from the IMF Direction of Trade Statistics (DOTS) for all country pairs in our sample in the period from 1978 to 2009. Data on manufactured goods, machinery and transport equipments, chemicals and related products, and food and beverages are taken from the OECD International Trade by Commodity Statistics. These data are available starting from 1988. The source of the data on interest rates is the International Financial Statistics of the IMF. The data on real bilateral exchange rates are obtained from the Bank of International Settlements. The exchange rate is defined in terms of the domestic currency $\left(P_{j} / P_{i}\right)$; that is, an increase indicates an appreciation of the real exchange rate.

\subsection{Empirical Specifications}

Our regression approach is conceptually straightforward. Specifically, let $F C_{i t}$ denote the domestic measure of fiscal consolidation in country $i$ in year $t$, and $F C_{j t}$ that in the foreign economy $j$ in year $t$. The IMF fiscal consolidation data express $F C_{i t}$ in percent of GDP. We construct a foreign "global" fiscal shock associated with country $i$ as:

$$
F C_{i t}^{*}=\sum_{j=1}^{16} \frac{\omega_{i j} F C_{j t} G D P_{j t}}{\omega_{i j} G D P_{j t}}
$$

where $\omega_{i j}$ is a bilateral weight associated with the relative importance of a foreign country $j$ as a destination for exports of country $i$. Weights are computed as three-year lagged values of exports $s_{i j} /$ exports $_{i}$. Summary statistics for the domestic consolidations and for our constructed foreign fiscal consolidation variable can be found in table 1. We employ two models. Our first benchmark panel specification uses aggregate data and takes the form:

\footnotetext{
${ }^{3}$ For example, in 1997, Germany introduced fiscal consolidation measures reaching 1.6 percent of GDP to reduce deficit primarily motivated by conforming to budget deficit criteria for the EMU accession.
} 


$$
\Delta x_{i, t}=\sum_{k=1}^{L} \beta_{k} \Delta x_{i, t-k}+\sum_{k=0}^{M} \gamma_{k} F C_{i, t-k}+\sum_{k=0}^{N} \delta_{k} F C_{i, t-k}^{*}+\Lambda Q_{i, t}+\alpha_{i}+\theta_{t}+\epsilon_{i, t}
$$

where $\Delta x_{i, t}$ is either the growth rate of output of country $i$ in year $t$, or the growth rate of the log of exports, or the change in the interest rate, or the change in the real exchange rate. ${ }^{4}$ The country-fixed effect, $\alpha_{i}$, captures time-invariant country-specific effect whereas the timefixed effect $\theta_{t}$ captures common global year-specific effects such as shocks to oil prices, and the vector $Q$ includes further controls such as lagged foreign and domestic income changes. We include lagged values of the fiscal consolidation measure to trace out the dynamics following a foreign fiscal consolidation.

Alternatively, instead of relying on the global fiscal shock as defined above, our second specification is at the bilateral level:

$$
\Delta x_{i j, t}=\alpha+\sum_{k=1}^{L} \beta_{k}^{(i)} \Delta x_{i j, t-k}+\sum_{k=0}^{M} \gamma_{k}^{(i)} F C_{i, t-k}+\sum_{k=0}^{N} \delta_{k}^{(i)} F C_{j, t-k}+\alpha_{j}^{(i)}+\theta_{t}^{(i)}+e_{j, t}^{(i)} .
$$

We estimate equation (3) for each domestic economy. That is, we hold $i$ fixed and treat the data as a panel of the trading partners of country $i$ over time. We execute this specification for every country in our sample and plot country-specific impulse response functions allowing us to examine potential heterogeneous responses across countries to foreign fiscal consolidation actions. Note that the fixed-effect $\alpha_{j}^{(i)}$ in equation (3) captures heterogeneities at the bilateral level such as those related to distance, to legal origin, and to sharing a language. We estimate equations (2) and (3) as a standard fixed effects panel data model, and we set $L=2$ and $M=N=3$. Further, we include lagged values of the dependent variable to allow for the persistence typically found in those relationships. For instance, Eichengreen and Irwin (1997) argue that trade flows cannot adjust quickly on account of large up-front investments, supporting the inclusion of the lagged dependent variable in trade-gravity models. Since our model includes lagged values of the dependent variable, some readers might be concerned

\footnotetext{
${ }^{4}$ In some exercises, we use other variables such as imports and net exports.
} 
about the Nickell bias. However, we also obtain results from the Arellano-Bond approach. These results tend to be similar results to those obtained from a panel fixed effects model. This finding is in line with the literature dealing with the question of how to estimate a gravity model. Our reading of the consensus in the literature is that the fixed effects estimation of gravity models, the dynamic OLS estimation, and the Arellano-Bond approach give similar results. $^{5}$

Also, we provide further results by employing in both specifications (2) and (3) additional dependent variables based on disaggregated trade data at the commodity level. Specifically, instead of using total export (whether at the aggregate level or at the bilateral level), we run a number of regressions using subcategories of total exports as the dependent variable including manufactured goods, machinery and transport equipments, chemicals and related products, and food and beverages.

\subsection{What Does Our Model Identify?}

We illustrate the conditions under which we identify a spillover effect with a causal interpretation by considering a general framework borrowed from Mendel (2012).

Let a bilateral measure $y_{i j, t}$ be a function

$$
y_{i j, t}=f\left(\epsilon_{t}, \epsilon_{i t}, g_{i t}, \epsilon_{j t}, g_{j t}\right)
$$

where $\epsilon_{t}$ represents a global shock to economic conditions, $\epsilon_{k t}$ is a country-specific economic shock in country $k$ (where $k=i, j$ ), and $g_{k t}$ is a shock to fiscal policy in country $k$. A first-order Taylor expansion of $f()$ around the zero steady state yields

$$
y_{i j, t}=f_{1} \epsilon_{t}+f_{2} \epsilon_{i t}+f_{3} g_{i t}+f_{4} \epsilon_{j t}+f_{5} g_{j t}
$$

with $f_{l}$ being the derivative of $f()$ with respect to the $l$ th argument. The effect of a fiscal policy shock in country $j$ on the bilateral measure $y_{i j, t}$ is then given by $f_{5}$. When can we hope to identify $f_{5}$ ?

From equation (5), we can derive the following necessary conditions:

\footnotetext{
${ }^{5}$ See, for instance, Bun and Klaassen (2002) and Fidrumc (2009).
} 
- The shock to global economic conditions must be uncorrelated with the foreign fiscal policy shock.

- The shock to domestic economic conditions must be uncorrelated with the foreign fiscal policy shock.

- The measure of foreign fiscal policy is uncorrelated with the foreign economic conditions.

- We do not have to assume that fiscal policies across countries are uncorrelated, since we can control for fiscal shocks in the domestic and foreign economies.

If $F C_{i}$ includes effects of demand-driven and other fiscal policies that are taken in reaction to the state of the economy, our specifications yield biased results. However, as we already mentioned, we employ the data of Devries et al. (2011). This measure of $F C_{i}$ is based only on those actions that are not taken in reaction to the business cycle, so this measure should be uncorrelated with current economic conditions. In other studies, as for example in Alesina and Ardagna (2010), a traditional measure of fiscal adjustment is defined as an increase in the cyclically adjusted primary budget surplus. The World Economic Outlook (2010, chapter 3) and Guajardo et al. (2011) provide a comparison of these narrative records with changes in the cyclically adjusted primary balance. These studies argue that the cyclically adjusted primary balance is subject to concerns of reverse causality when, e.g., policy-makers raise taxes in response to high aggregate demand (this argument is made in Romer and Romer, 2010), and that the cyclically adjusted primary balance might not reflect changes in fiscal policy that are orthogonal to the business cycle. For instance, even in the absence of a fiscal consolidation, the cyclically adjusted primary balance may rise in response to capital gains.

Yet, how is our identification strategy related to existing studies on fiscal spillover effects? There are only few related empirical studies. For example, based on a panel of only European countries and using a Vector Autoregression (VAR) model, Beetsma, Giuliodori, and Klaassen (2006) estimate the effect of an increase in government spending on output. Given this measure of the shock and under the assumption that outputs of all countries react with an identical magnitude to a spending shock, in a second step, the authors estimate the effects of this measure on trade, and find support for a positive spillover effect. Another related study to ours is by Auerbach and Gorodnichenko (forthcoming) who employ panel data techniques 
in a panel of OECD countries, distinguish between the effect of fiscal policy in recessions and expansions, and find large effects of foreign fiscal policies on domestic output. Our results are novel in three regards: 1) Our measure of the fiscal shock is a policy measure, 2) we analyse the various channels of transmitting fiscal effects across the border; particularly the trade channel, and 3) we rely on a panel of bilateral data for OECD countries. Whereas our paper is one of the first to use the narrative approach to estimate international effects of fiscal policy, a recent study by Feyrer and Jay (2012) follows a similar approach. However, Feyrer and Jay (2012) focus only on the US. Specifically, they employ Romer and Romer's (2010) narrative measure of U.S. tax policy to estimate the effects of U.S. tax changes on the current account of the rest of the world. Their main finding is that an increase in U.S. taxes leads to an increase in investment outside the U.S.

\section{Results}

\subsection{Main Results}

We begin by examining spillover effects of foreign fiscal consolidation actions on output. The solid line in figure 3 presents the Impulse Response Function (IRF) of output obtained from specification (2). The dashed lines represent the 90 percent confidence interval. In line with theory, the dynamics in figure 3 suggests a significant negative effect on domestic output resulting from fiscal contractions in foreign countries. Strikingly, the effect on output is large: A $1 \%$ foreign fiscal consolidation reduces domestic GDP by $3 \%-7 \%$ in the same year $(90 \%$ confidence interval). This finding is consistent with the empirical results reported in Auerbach and Gorodnichenko (forthcoming). While it is intriguing, it raises the need to have a closer look at the transmission mechanisms through which cross-border effects of fiscal policy may occur. Based on the above theoretical overview, we use specification (2) to examine the transmission mechanism by plotting the IRFs of exports, imports, net exports, interest rate, and the real exchange rate, following a 1-percent shock to foreign fiscal consolidations $\left(F C_{i t}^{*}\right)$. Figure 4 displays the results. Exports decline in reaction to a foreign consolidation shock, supporting the importance of the trade channel of spillover as predicted by the MundellFleming model described in section 2.1. However, we do not find powerful effects on the 
domestic interest rate or the real exchange rate suggesting that international trade is an important channel of the cross-border transmission of a foreign fiscal shock.

To gain deeper insights, we focus on the trade channel and examine in figure 5 the dynamics of exports following a shock to foreign fiscal consolidations obtained from specification (3). This strategy enables us to plot country-specific reactions to foreign fiscal policy. Figure 5 reveals that whenever the response of exports to a foreign consolidation is significant, it is negative. This is the case for some European countries such as France, Germany, Sweden, and the UK. A $1 \%$ foreign fiscal consolidation reduces exports of the domestic economy by about 1\%-4\% (90\% confidence interval). However, exports of Australia, Canada, Japan, and the U.S. seem to not be significantly affected by foreign fiscal consolidation shocks. A potential explanation is that these European countries depend more on exports, and hence on income in the rest of the world. For example, according to table 3, in 2007, Germany had the highest ratio of exports to world exports, reaching 9.43 percent. In the case of France, Italy, and the UK this ratio is also high, amounting to 4, 3.6, and 3.1 percent, respectively. However, Japan and Canada, indeed, also have fairly high export ratios, which does not lend support to this hypothesis. Alternatively, the difference might be in relation to the relative importance of trading partners. Although Japanese exports constitute about 4.5 percent of world exports, the ratio is substantially lower if we consider only those partner countries included in the IMF consolidation data. Canada is a slightly different example. Its main export partner is the U.S. But its dependence on the U.S. market is extremely high, reaching 78 percent of total Canadian exports in 2007. In principle, the effect can be identified in our approach, since we have weighted countries' interconnections according to their relative bilateral importance. However, the lack of a portfolio of export destinations (containing an extraordinarily large weight, as in the case of Canada) means that cross-country variation is not as important for the incidence of cross-border effects as policy variation over a long time series occurring in that particular main trading partner country.

Our findings complement the results of Feyrer and Jay (2012) that suggest that an increase in U.S. taxes leads to an increase in investment outside the U.S. Our results show that fiscal spillover effects exist especially in Europe and point out that the effects on external balances occur mainly through the channels of international trade. This is important because, recalling 
our finding of the insignificant reaction of the interest rate to foreign consolidations, one can interpret the changes in the current account, reported in Feyrer and Jay (2012) as mainly driven by the financing of international trade rather than by receiving capital income.

Since openness to international trade, as captured by ratio of exports, may not provide the full explanation for the reported heterogeneous responses across countries in our sample, we explore another possibility. Countries may have different trade intensities of different trade categories that might be differently affected by foreign fiscal policies. If that is the case, then the different intensities of exports may explain the heterogeneous responses. We examine this hypothesis by re-running regression specification (3) using disaggregated series of bilateral trade by commodity. We focus on four mjaor different categories of commodities in our analysis: 1) Manufactured goods, 2) machinery and transport equipments, 3) chemicals, and 4) the series including the rest of categories, essentially, food and beverages, etc. Figures 6 and 7 show the results. These figures do not deliver conclusive evidence in favor of the hypothesis. Regardless of the exported commodity, U.S. exports do not show a significant reaction to the fiscal policies in the rest of the world. The figures indicate that exports of machines and/or manufactured goods of Germany, France, Italy, and Sweden show reactions that are generally consistent with the series of aggregate exports. Detailed countries' experiences vary. For example, Germany and Italy show a stronger reaction in manufacturing. However, results at this level do not reveal systematic differences in a way that fully explains heterogeneous sensitivities to foreign fiscal policies. A higher disaggregation level and firm-level data might help to explain our macro results by revealing detailed information on the exported products and their relevant importance among countries. We think that this should be investigated further in future research. Still, the aggregate results are informative and microanalysis would require a different identification scheme since the IMF action-based data vary only at the country level and over time and not at the product or firm level.

\subsection{Extension of Main Results}

The pattern we have reported so far is that exports of some European countries react significantly negatively to foreign fiscal consolidation actions whereas exports of the US, Canada, and Japan do not. In this section, we consider further dimensions of differences that may 
affect cross-borders effects of fiscal policy and may explain these reported heterogeneous responses. We extend our main results by considering two aspects. First, we test whether or not the formation of the euro area affects our results. Second, we address the possibility that the effects of fiscal adjustments depend on the state of the economy, in particular, on whether or not the foreign economy is experiencing a banking crisis.

\subsubsection{Cross-Border Effects of Fiscal Consolidations before and after the EMU}

We examine whether the common currency in the euro area can provide deeper insights. It is well known that the conduct of monetary policy can affect the effectiveness of fiscal policy. A number of European countries in our sample have joined a currency union, and hence share a common monetary policy since 1999 at the union level. Since our results indicate that European countries show significant reactions to foreign fiscal consolidation actions, it is worthwhile to check whether this effect is driven by the common currency. We perform a before-after analysis based on specification (3). One might expect that in the era pre the EMU cross-border effects of fiscal consolidation are insignificant, and become significant after the EMU. According to figure 8, however, the response of exports to foreign fiscal policy does not seem to be systematically different before and after the euro. It should be noted that even before the introduction of the euro, member countries engaged in the European Exchange Rate Mechanism allowing their currencies to fluctuate only within a certain narrow margin. This pre-euro exchange rate arrangement might explain the pattern presented in the figure 8. In sum, there seems to be no evidence supporting a systematic difference in fiscal spillover effects before and after the introduction of the euro.

\subsubsection{Cross-Border Effects of Fiscal Consolidations in Episodes of Crises}

The power of fiscal policy may depend on the state of the economy. This insight is revealed by Keynesian theoretical reasoning and also by modern micro-founded general equilibrium models. ${ }^{6}$ For example, in a recession output is below its trend level and a fiscal expansion can be effective in stimulating demand. Specification equations like (2) or (3) are common in the literature, but they restrain the effect of fiscal policy to be the same over the cycle. In

\footnotetext{
${ }^{6}$ See, for example, Michaillat (forthcoming).
} 
order to allow for different spillover effects of fiscal consolidation in crisis and noncrisis times, we re-estimate specifications (2) and (3) after augmenting it with a variable taking the value 1 in periods of banking crises and zero otherwise $\left(\right.$ Crisis $\left._{i}\right)$ and an interaction term between this variable for the foreign economy $\left(\right.$ Crisis $\left._{i}\right)$ and $\left(F C_{i}^{*}\right)$ :

$$
\begin{aligned}
\Delta x_{i, t}= & \sum_{k=1}^{L} \beta_{k} \Delta x_{i j, t-k}+\sum_{k=0}^{M} \gamma_{k} F C_{i, t-k}+\sum_{k=0}^{N} \delta_{k} F C_{i, t-k}^{*} \\
& +\sum_{k=0}^{M} \phi_{k} \text { Crisis }_{i, t-k}+\sum_{k=0}^{M} \pi_{k} \text { Crisis }_{j, t-k} \\
& +\sum_{k=0}^{M} \zeta_{k}\left(\text { Crisis }_{i, t-k} \times F C_{i, t-k}^{*}\right)+\theta_{t}+\psi_{j}+\epsilon_{i j, t} .
\end{aligned}
$$

In additional, we examine whether the transmission of foreign fiscal consolidation depends on the occurrence of a banking crisis in the foreign economies by including the interaction term $\left(\right.$ Crisis $\left._{j}\right)$ and $\left(F C_{j}\right)$. The above specification is related to the work of Auerbach and Gorodnichenko (2012a; 2012b), who were among the first to empirically consider the magnitude of the government spending multiplier in recessions. Here, we consider the case of fiscal consolidations, allowing cross-border effects of a fiscal consolidation to differ depending on episodes of macroeconomic crises. We define a year as a crisis year based on dates for banking crises as provided by Reinhart and Rogoff (2011). Table 2 summarises these episodes in our sample.

Figure 9 shows the results. The leftmost panel shows the baseline effect of a foreign fiscal consolidation on exports when there is no crisis in either the domestic or foreign economy. The center panel shows the impulse response of exports to a foreign consolidation shock when the fiscal consolidation takes place in a period of banking turmoil in foreign countries whereas the rightmost panel shows the impulse response when the foreign fiscal consolidation takes place during a domestic banking crises. Exports show a significant negative reaction to foreign fiscal contractions regardless of the state of the banking system in either the domestic or the foreign economy. Due to the small number of banking crises in our sample, a higher statistical power is required for stronger statements about the potentially different effect size 
across states of the economy.

\section{Conclusions}

In the ever increasing economic integration of the world economy, and in light of the current unprecedented challenges facing the conduct of fiscal policy, many embrace the view that domestic policy actions can be transmitted to other economies. This paper has focused on potential international transmission mechanisms of fiscal adjustments as identified by recently published data constructed using narrative records for 17 advanced economies. The contributions of our study are: First, we provide further evidence that foreign fiscal consolidations negatively affect domestic output, complementing recent work by Auerbach and Gorodnichenko (2013). Second, we examine the channels of international transmission of fiscal consolidations. We find that the effect works mostly through trade linkages, and we cannot find strong evidence for an interest rate channel or an exchange rate channel. Third, when we look at bilateral trade flows, we find that European countries are particulary vulnerable to foreign fiscal policies, whereas US exports do not react to foreign fiscal shocks. Fourth, using bilateral data on commodities' exports for OECD countries, we find that machines and manufactured goods are among the commodities that show pattern that is consistent with the results obtained for aggregate exports. Still, however, all results consistently show that contrary to the case of some European countries, the US does not significantly react to foreign fiscal shocks. Further, we have analysed whether membership in the European Monetary Union can explain the reported heterogeneous reactions. Results do not lend support to this hypothesis. As a final extension, we have addressed the question whether or not the spillover effects of fiscal consolidations are different in periods of banking crises from those in noncrisis episodes in the foreign country. We find no clear-cut evidence of differential reactions of exports depending on the incidence of banking crises. The exact reasons behind the heterogeneous reactions of countries' exports to foreign fiscal actions are an important and potentially fruitful area for further research. 


\section{References}

Alesina, A., and Ardagna, S. (2010) Large changes in fiscal policy: Taxes vs. spending, Tax Policy and the Economy 24: 35-68.

Alesina, A., and Ardagna, S. (1996) Tales of fiscal adjustment, Economic Policy 13: $487-545$.

Auerbach, A., and Gorodnichenko, Y. (forthcoming) Output spillovers from fiscal policy, American Economic Review: Papers and Proceedings

Auerbach, A., and Gorodnichenko, Y. (2012a) Fiscal multipliers in recession and expansion, in Alberto Alesina and Francesco Giavazzi (Eds.), Fiscal Policy after the Financial Crisis, University of Chicago Press, 2012.

Auerbach, A., and Gorodnichenko, Y. (2012b) Measuring the output responses to fiscal policy, American Economic Journal: Economic Policy 2: 1-27.

Beetsma, R., Giuliodori, M., and Klaassen, F. (2006) Trade spill-over of fiscal policy in the European Union: a panel analysis, Economic Policy 21: 639-87.

Bun, M.J. and Klaassen, F.J. (2002), The importance of dynamics in panel gravity models of trade, mimeo, University of Amsterdam.

Carlino, G.A. and Inman, R.P. (forthcoming), Local deficits and local jobs: Can US states stabilize their own economics?, Journal of Monetary Economics.

Corsetti, G., Meier, A., and Müller, G. (2010) Cross-border spillovers from fiscal stimulus, International Journal of Central Banking 6: 5-37.

Cwik, T., and Wieland, V. (2011) Keynesian government spending multipliers and spillovers in the euro area, Economic Policy 67: 493-549.

Devries, P., Guajardo, J., Leigh, D., and Pescatori, A. (2011) A new action-based dataset of fiscal consolidation, IMF Working Paper No. WP/11/128.

Feyrer, J., and Jay S. (2012), Global savings and global investment: The transmission of identified fiscal shocks, American Economic Journal: Economic Policy 4: 95-114.

Eichengreen, B., and Irwin, D. (1997) The role of history in bilateral trade flows, NBER Working Paper No. 5565, Cambridge.

Fidrmuc, J. (2009) Gravity models in integrated panels, Empirical Economics 37: 435-446.

Giavazzi F., Pagano, M. (1990) Can severe fiscal contractions be expansionary? Tales of two small European countries, NBER Macroeconomics Annual 1990. 
Guajardo, J., Leigh, D., and Pescatori, A. (2011) Expansionary austerity: New international evidence, IMF Working Paper No. WP/11/158.

Hebous, S. (2011) The effects of discretionary fiscal policy on macroeconomic aggregates: A reappraisal, Journal of Economic Surveys 25: 674-707.

Hebous, S., and Zimmermann, T. (2013) Estimating the effects of coordinated fiscal actions in the euro area, European Economic Review 58: 110-121.

Kim, S. and Roubini, N. (2008) Twin deficit or twin divergence? Fiscal policy, current account, and real exchange rate in the U.S, Journal of International Economics 74: $362-83$.

Mendel, B. (2012) Local multipliers, Harvard University, mimeo.

Michaillat, P. (forthcoming) A theory of countercyclical government multiplier, American Economic Journal: Macroeconomics.

Monacelli, T. and Perotti, R. (2010) Fiscal policy, the real exchange rate, and traded goods, Economic Journal 120: 437-461

Obstfeld, M. and Rogoff, K. (1995) Exchange rate dynamic Redux, Journal of Political Economy 103: 624-660.

Reinhart, C., and Rogoff, K. (2010) This time is different chartbook: Country histories on debt, default, and financial crises. NBER Working Paper 15815, March 2010.

Romer, C, and Romer, D. (2010) The macroeconomic effects of tax changes: estimates based on a new measure of fiscal shocks, American Economic Review 100: 763-801.

World Economic Outlook (2010) Recovery, Risk, and Rebalancing. International Monetary Fund, September, 2010, Washington DC. 
Figure 1: Cross-Border Transmission Channels of Fiscal Consolidations

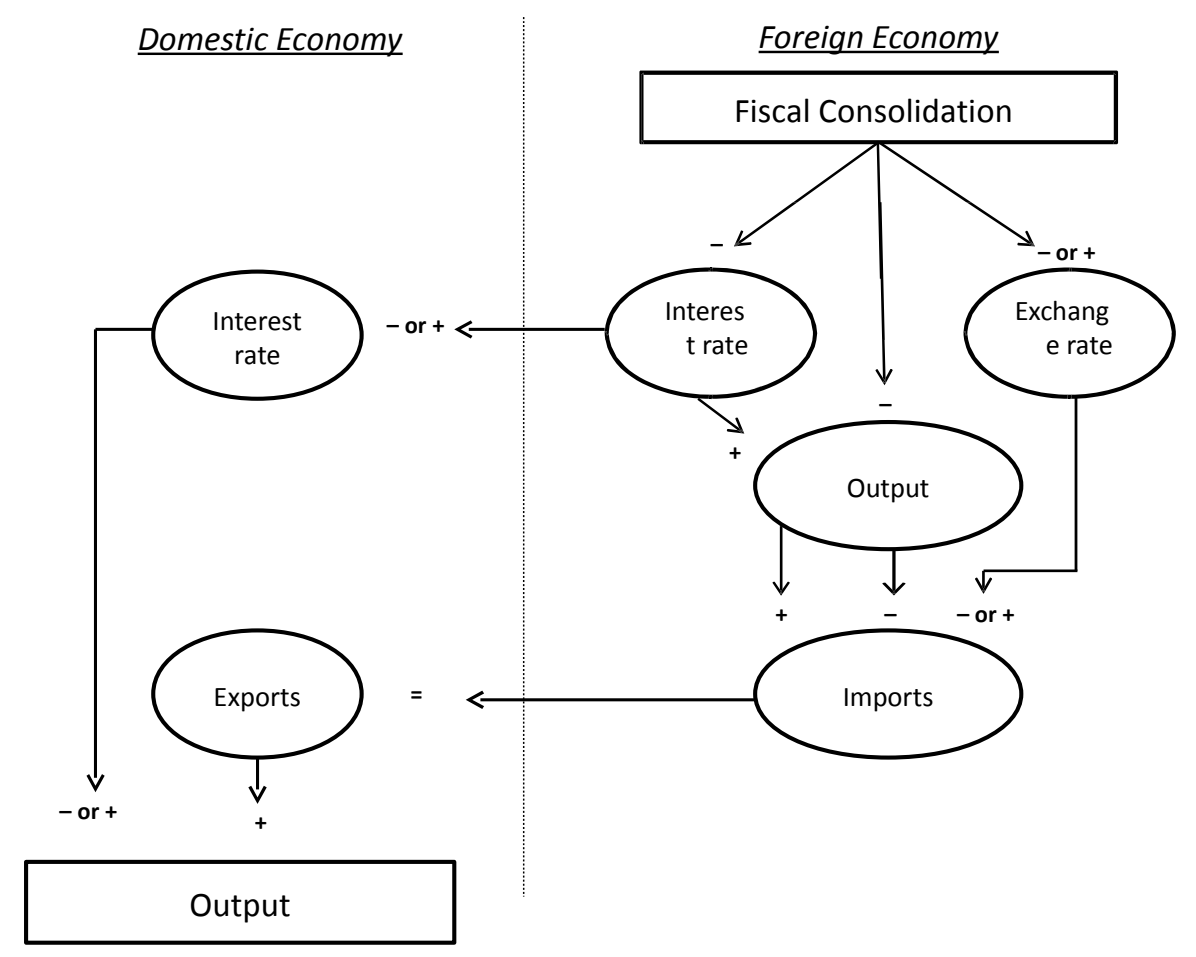


Figure 2: Fiscal Consolidation Episodes from Devries et. al. (2011)

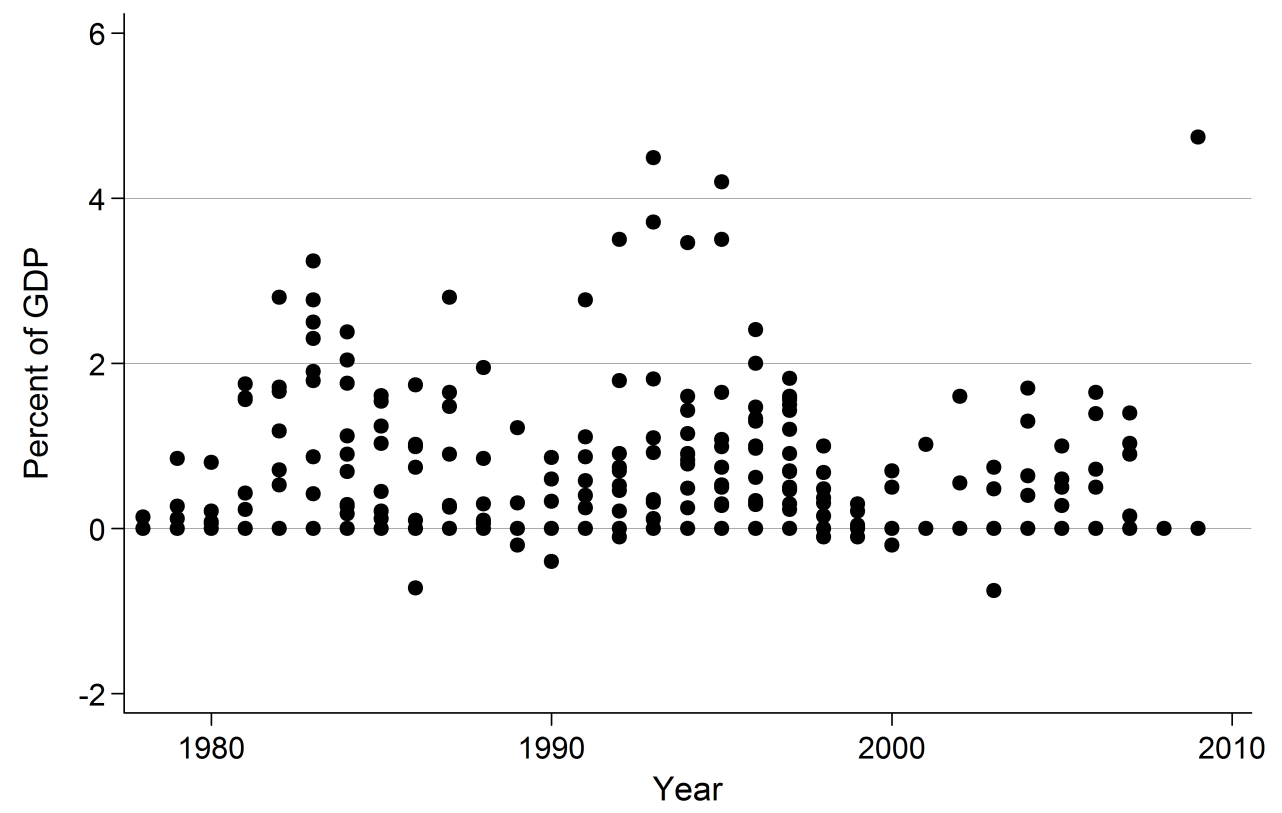

Figure 3: The Response of GDP to a 1\% Foreign Fiscal Consolidation Shock

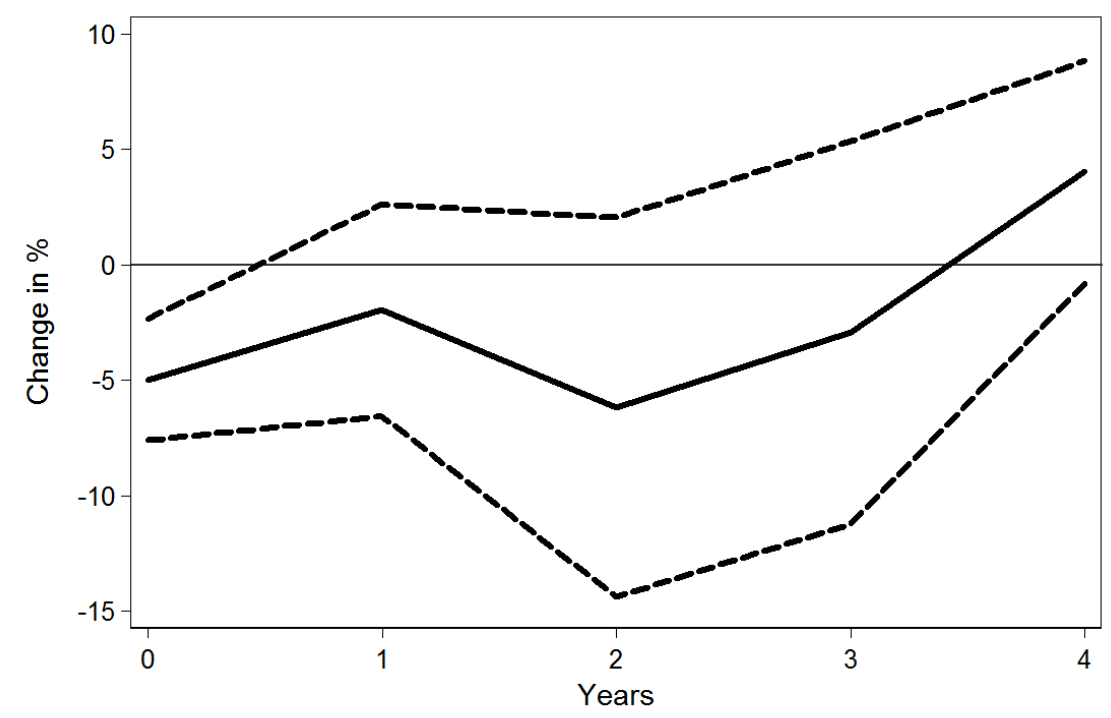

Note: The model is estimated in differences. The panels show the dynamics of output to a $1 \%$ foreign fiscal consolidation Shock. Standard errors are clustered at the foreign country level. Dashed lines present 90 percent confidence interval. 
Figure 4: The Transmission Mechanism of Cross-Border Effects of Fiscal Consolidation

(a) Exports

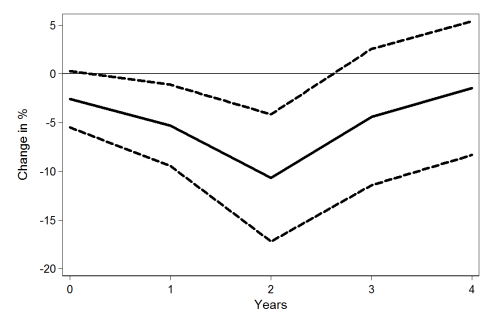

(c) Net exports

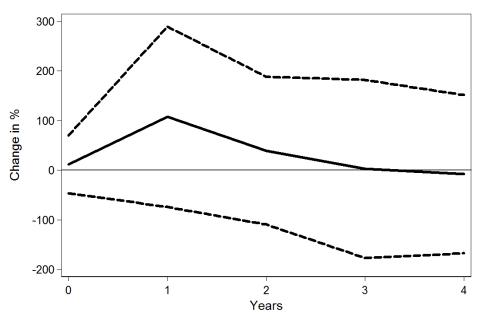

(e) Interest rate (long)

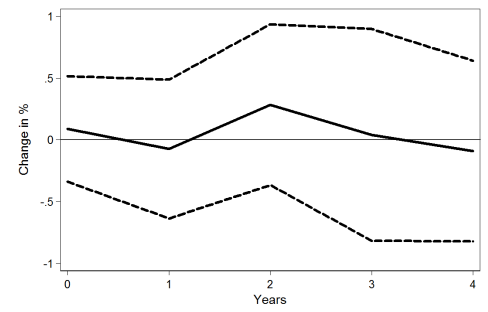

(b) Imports

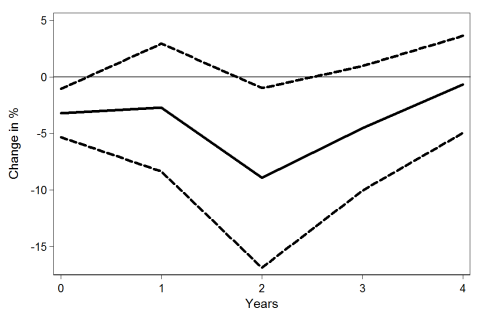

(d) Interest rate (short)

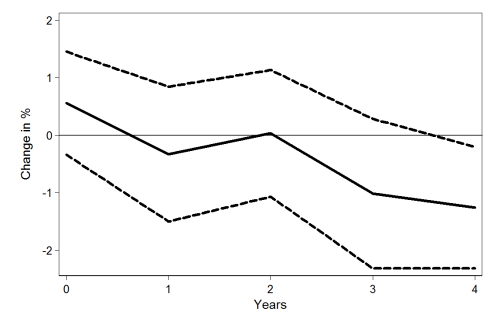

(f) Exchange rate

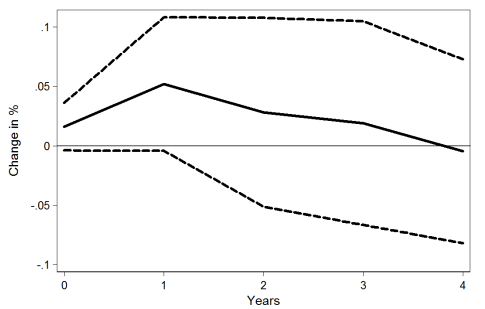

Note: The model is estimated in differences. The panels show the dynamics of selected variables to a $1 \%$ foreign fiscal consolidation Shock. Standard errors are clustered at the foreign country level. Dashed lines present 90 percent confidence interval. 


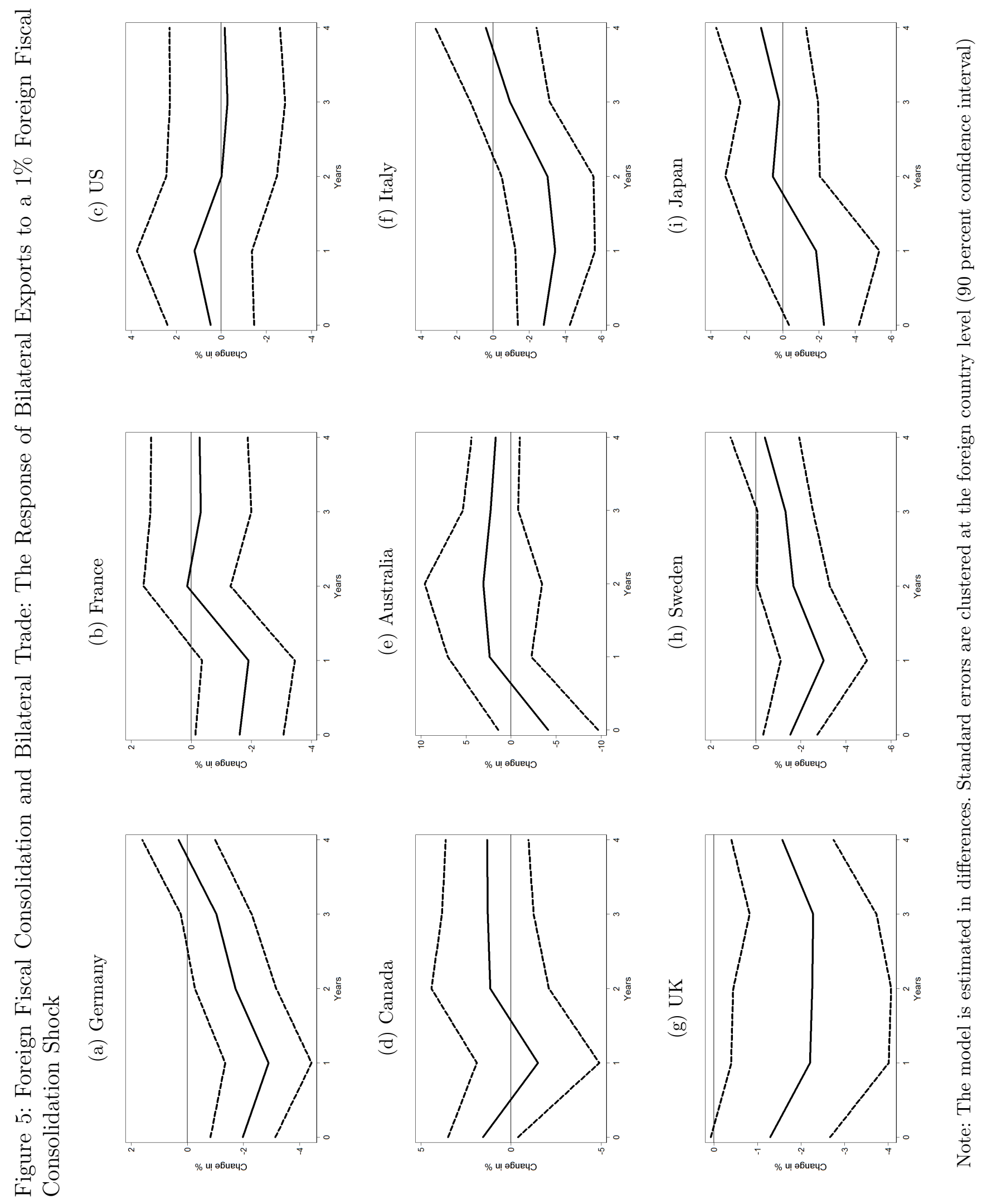




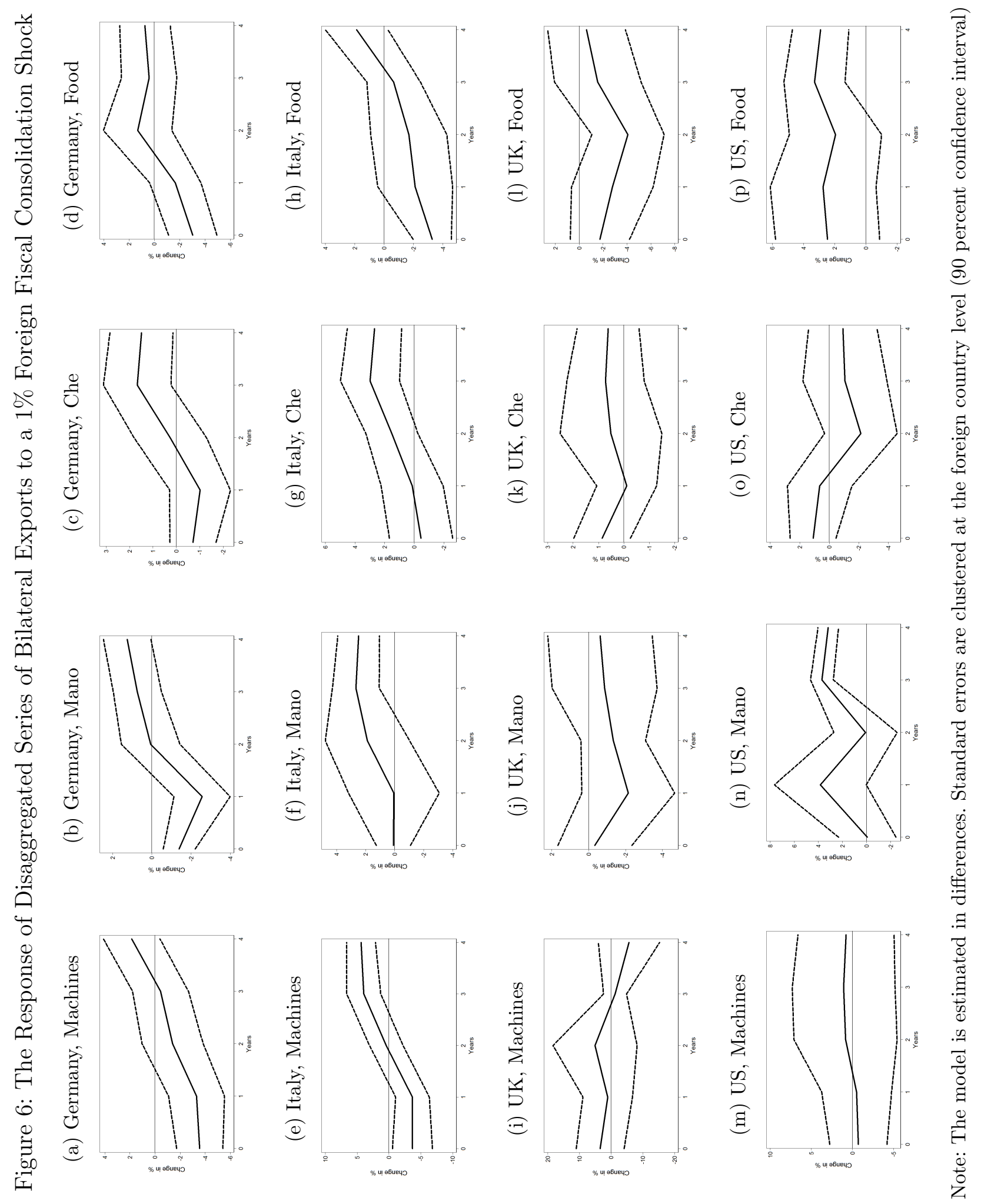




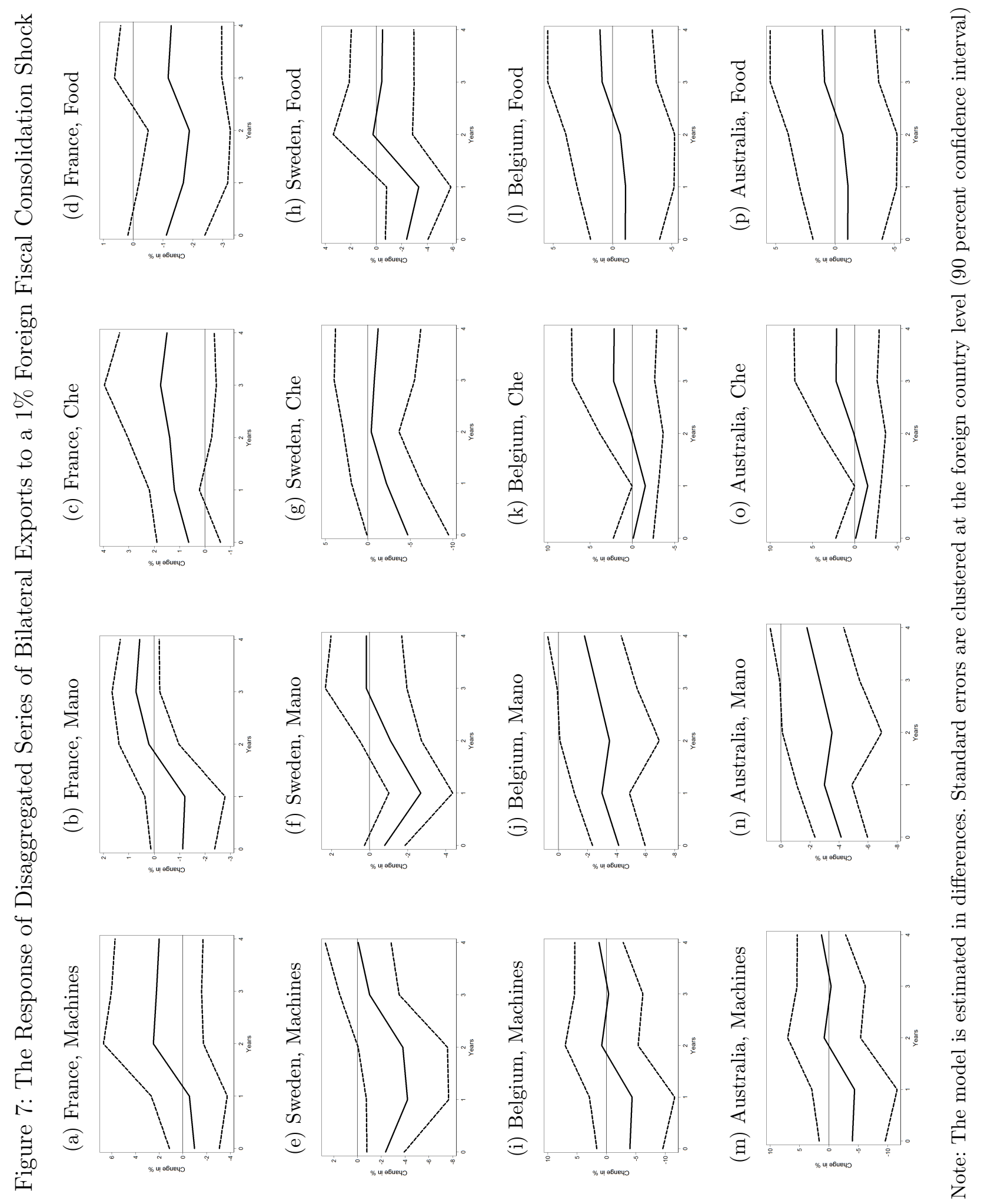




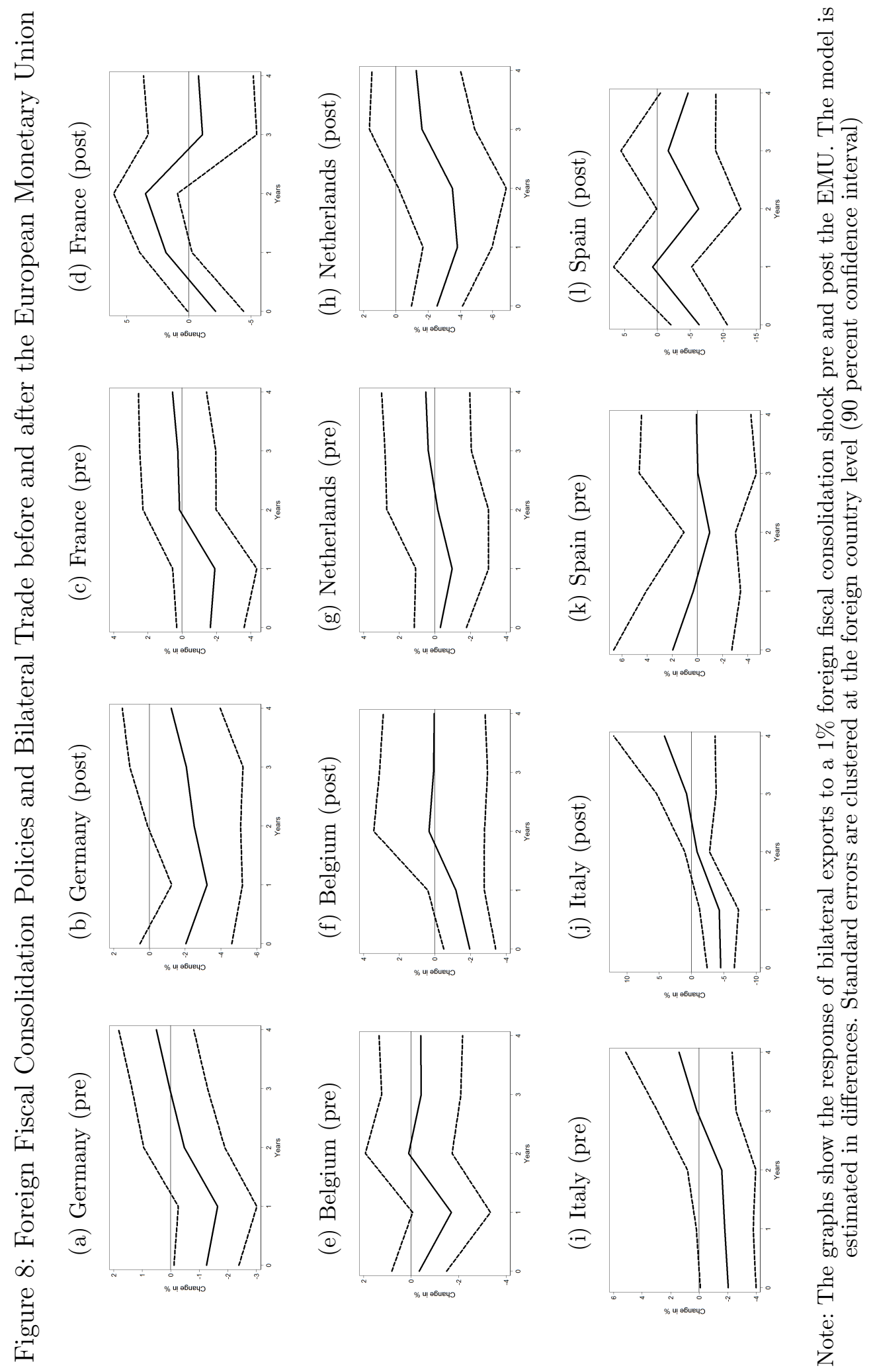




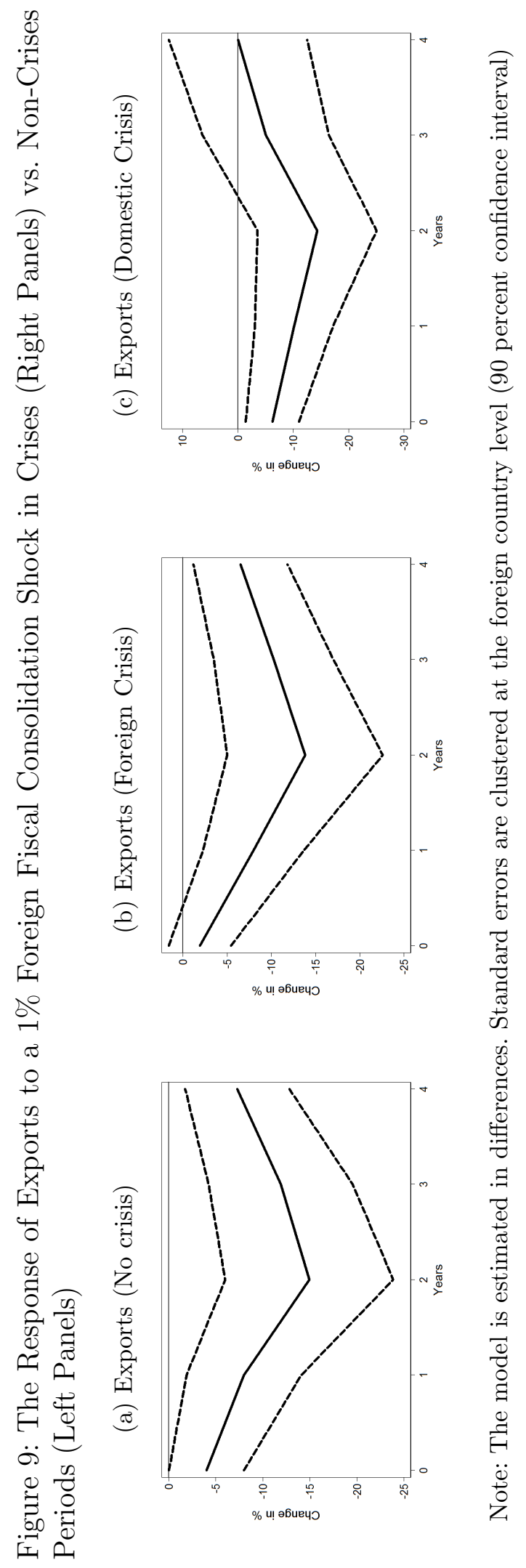


Table 1: Summary statistics for domestic and foreign consolidations

\begin{tabular}{lrrrrrrrr}
\hline \multirow{2}{*}{ Country } & \multicolumn{3}{c}{ Domestic consolidation } & \multicolumn{3}{c}{ Foreign consolidation } \\
& Mean & SD & Median & Non-zero episodes & Mean & SD & Median \\
\cline { 2 - 4 } \cline { 7 - 8 } Germany & .68 & .45 & .72 & 16 & .35 & .31 & .21 \\
France & .22 & .48 & .25 & 9 & .40 & .36 & .35 \\
Belgium & 1.36 & .65 & 1.15 & 11 & .32 & .28 & .28 \\
Netherlands & 1.30 & .86 & 1.48 & 13 & .34 & .33 & .23 \\
Italy & 2.00 & 1.40 & 1.41 & 12 & .26 & .24 & .17 \\
United Kingdom & .53 & .46 & .31 & 9 & .36 & .30 & .31 \\
Ireland & 1.85 & 1.53 & 1.80 & 8 & .27 & .27 & .17 \\
Denmark & 1.25 & 1.45 & 1.54 & 5 & .33 & .32 & .22 \\
Portugal & 1.04 & 1.01 & 1.40 & 7 & .30 & .28 & .18 \\
Spain & 1.05 & .62 & 1.16 & 10 & .32 & .28 & .25 \\
Sweden & 1.64 & .94 & 1.50 & 7 & .31 & .28 & .19 \\
Finland & 1.91 & 1.39 & 1.56 & 6 & .31 & .30 & .22 \\
Austria & 1.42 & .67 & 1.56 & 7 & .38 & .39 & .24 \\
United States & .38 & .26 & .31 & 14 & .29 & .23 & .28 \\
Canada & .57 & .32 & .44 & 14 & .19 & .23 & .09 \\
Japan & .54 & .35 & .48 & 11 & .23 & .22 & .15 \\
Australia & .50 & .32 & .48 & 10 & .23 & .23 & .17 \\
\hline
\end{tabular}


Table 2: Export Shares (in Percent, 2007)

\begin{tabular}{lcc}
\hline & $\begin{array}{c}\text { Share of exports in } \\
\text { world total exports }\end{array}$ & $\begin{array}{c}\text { Share of exports to countries } \\
\text { in the sample in total exports }\end{array}$ \\
\hline Australia & 1.01 & 37.66 \\
Austria & 1.17 & 62.04 \\
Belgium & 3.08 & 78.06 \\
Canada & 3.00 & 88.75 \\
Denmark & 0.74 & 73.26 \\
Finland & 0.64 & 57.62 \\
France & 3.99 & 68.62 \\
Germany & 9.43 & 62.40 \\
Ireland & 0.87 & 82.38 \\
Italy & 3.57 & 59.12 \\
Japan & 5.10 & 37.24 \\
Netherlands & 3.93 & 77.80 \\
Portugal & 0.37 & 81.05 \\
Spain & 1.81 & 72.38 \\
Sweden & 1.20 & 65.28 \\
United Kingdom & 3.13 & 72.53 \\
United States & 8.19 & 48.72 \\
\hline
\end{tabular}

Source: WTO and DOTS of the IMF. 
Table 3: Years of Banking Crises

\begin{tabular}{|c|c|c|c|c|c|c|c|}
\hline Year & Country & Year & Country & Year & Country & Year & Country \\
\hline 1979 & DEU & 2008 & GBR & 1985 & ESP & 2007 & USA \\
\hline 2008 & DEU & 2009 & GBR & 2008 & ESP & 2008 & USA \\
\hline 2009 & DEU & 2007 & IRL & 2009 & ESP & 2009 & USA \\
\hline 1994 & FRA & 2008 & IRL & 1991 & SWE & 1983 & $\mathrm{CAN}$ \\
\hline 1995 & FRA & 2009 & IRL & 1992 & SWE & 1984 & $\mathrm{CAN}$ \\
\hline 2008 & FRA & 1987 & DNK & 1993 & SWE & 1985 & $\mathrm{CAN}$ \\
\hline 2009 & FRA & 1988 & DNK & 1994 & SWE & 1992 & JPN \\
\hline 2008 & BEL & 1989 & DNK & 1991 & FIN & 1993 & JPN \\
\hline 2009 & BEL & 1990 & DNK & 1992 & FIN & 1994 & JPN \\
\hline 2008 & NLD & 1991 & DNK & 1993 & FIN & 1995 & JPN \\
\hline 2009 & NLD & 1992 & DNK & 1994 & FIN & 1996 & JPN \\
\hline 1990 & ITA & 2008 & DNK & 2008 & AUT & 1997 & JPN \\
\hline 1991 & ITA & 2009 & DNK & 2009 & AUT & 1998 & JPN \\
\hline 1992 & ITA & 2008 & PRT & 1984 & USA & 1999 & JPN \\
\hline 1993 & ITA & 2009 & PRT & 1985 & USA & 2000 & JPN \\
\hline 1994 & ITA & 1979 & ESP & 1986 & USA & 2001 & JPN \\
\hline 1995 & ITA & 1980 & ESP & 1987 & USA & 1989 & AUS \\
\hline 1984 & GBR & 1981 & ESP & 1988 & USA & 1990 & AUS \\
\hline 1991 & GBR & 1982 & ESP & 1989 & USA & 1991 & AUS \\
\hline 1995 & GBR & 1983 & ESP & 1990 & USA & 1992 & AUS \\
\hline 2007 & GBR & 1984 & ESP & 1991 & USA & & \\
\hline
\end{tabular}

Source: Reinhart and Rogoff (2010). 